\title{
RHEOLOGICAL PROPERTIES OF NANOCOMPOSITES BASED ON BIFUNCTIONAL CLINOPTILOLITE AND ETHYLENE/HEXENE COPOLYMER
}

\author{
I.V.Bayramova \\ Institute of Polymer Materials, NAS of Azerbaijan \\ najaf1946@rambler.ru
}

Received 20.06.2019

Accepted 02.10.2019

\begin{abstract}
The results of a study of the influence of temperature and shear stress on the rheological properties of ethylene/hexene copolymer and its clinoptilolite-filled nanocomposites are presented. Rheological measurements were carried out in the temperature range of $190-250^{\circ} \mathrm{C}$. The dependence of shear rate on shear stress, effective melt viscosity on shear rate, and melt viscosity on temperature in Arrhenius coordinates is studied. Using the universal temperature-invariant viscosity characteristics of nanocomposites allows to make approximate calculations of effective viscosity close to the conditions of their processing by extrusion and injection molding by extrapolation to the region of high shear rates.
\end{abstract}

Keywords: viscosity, shear rate, shear stress, nanocomposites, polymer melt, clinoptilolite.

doi.org/10.32737/0005-2531-2020-2-83-89

\section{Introduction}

With the development of modern industry, an increasing need arises in new and highquality polymer composite materials designed for use in harsh extreme conditions. Various types of polymers produced in the polymer industry have fairly good physico-mechanical properties due to which they can be processed on high-performance equipment. However, the development of such industries as aviation, shipbuilding, engineering, military and space dictate the need to create new types of polymer materials capable of working in harsh extreme operating conditions. To this end, various methods are being used to modify the structure and properties of polyolefins, allowing to any extent to approach the implementation of the task [14]. The most common are modification methods such as plasticization, the introduction of thermal and light stabilizers, various types of polymer and mineral fillers, mixing polymer with polymer, physical and chemical crosslinking etc. Over the past 10 years, there has been a significant increase in interest in the use of ultrafine mineral fillers of the nanoscale level, which have made it possible to make a significant breakthrough in the direction of creating durable, heat- and thermo-stable, light and chemical-stable composite materials. Despite the successes achieved in this direction, research aimed at studying the processability of nanocomposite materials is very limited. An important attribute that determines the ability of a polymer to be processed by injection molding and extrusion methods is their comprehensive rheological studies over a wide range of temperatures and shear stresses [5-8].

Therefore, the aim of this work is to study the rheological features of the behavior of the melt of nanocomposites depending on the filler concentration, temperature, and shear stress.

\section{Experimental part}

As the polymer matrix was used ethylene/hexene-1 copolymer (CEH) of the PE6438R brand, characterized by the following properties: density $-0.932 \mathrm{~g} / \mathrm{cm}^{3}$, breaking stress $-37.4 \mathrm{MPa}$, elongation at break $-810 \%$, flexural modulus - $712 \mathrm{MPa}$, melting temperature $-127^{\circ} \mathrm{C}$, Vicat softening temperature $115^{0} \mathrm{C}$, melt flow index (MFI) $-5.12 \mathrm{~g} / 10 \mathrm{~min}$, crystallinity degree $-75 \%$.

Clinoptilolite (CTL) of the Aydag deposit of Azerbaijan, whose typical oxide formula is $\left(\mathrm{Na}_{2} \mathrm{~K}_{2}\right) \mathrm{OAl}_{2} \mathrm{O}_{3} \cdot 10 \mathrm{SiO}_{2} \cdot 8 \mathrm{H}_{2} \mathrm{O}$, and the probable crystalline one is $\mathrm{Ca}_{4,5} \mathrm{Al}_{9} \mathrm{SiO}_{24} \mathrm{O}_{72}$. The finely dispersed CTL was presented by the Institute of Geology and Geophysics of the National Academy of Sciences of Azerbaijan. 
CTL nanoparticles were obtained in an A-11 analytical mill at a maximum speed of $30.000 \mathrm{rpm}$.

The size of the nanoparticles was determined on an instrument of the STA PT1600 Linseiz model (Germany) and was 20-110 nm.

Polymer nanocomposites based on $\mathrm{CEH}$ and CTL were obtained by mixing on rollers at a temperature of $170^{\circ} \mathrm{C}$. After melting of $\mathrm{CEH}$ on rollers CTL was added in portions for 8 minutes. On the basis of the obtained polymer composite, $2 \mathrm{~mm}$ thick plates were pressed at a temperature of $190^{\circ} \mathrm{C}$, the exposure time under pressure was 30 minutes. Under a pressure of $90 \mathrm{MPa}$, the temperature of the pressed plate was reduced to $130^{\circ} \mathrm{C}$. On the basis of the obtained plate, blades were cut to determine the breaking stress and elongation of the samples in accordance with GOST 11262-80.

Heat resistance was determined by the method of Vicat.

Rheological studies of polymer materials were carried out on a MELT FLOW TESTER, CEAST MF50 capillary rheometer (INSTRON, Italy) in the temperature range of $170-230^{\circ} \mathrm{C}$ and in the load range of $2.16-21.6 \mathrm{~kg}$, the ratio of nozzle length to capillary diameter is 24 .

\section{Results and its discussion}

Rheology is not only the theoretical basis for the processing of polymers, but also allows you to get quite complete information about the behavior of the melt in the material cylinder. The study of this issue becomes even more relevant when it comes to optimizing the technological regime of processing polymer composites into specific types of products. In practice, as a rule, they are limited to using such a characteristic of the rheology of polymers as the melt flow index (MFI), which basically allows us to distinguish between technological methods of their processing. But this indicator does not at all reveal the rheological features of the composite melt close to the actual processing conditions by extrusion and injection molding.

Therefore in this work, on the example of $\mathrm{CEH}$ and the natural mineral CTL, we considered the rheological features of the melt flow of nanocomposites in the temperature range of $190-250^{\circ} \mathrm{C}$ and a load in the range of $2.16-21.6$ $\mathrm{kg}$. It should be noted that nanoparticles, in contrast to conventional dispersed fillers, are characterized by a very developed surface, which allows them to interact with the macromolecule macrosegments at the molecular level. Research on the rheological properties of nanocomposite polymer materials, conducted over the years under the leadership professor N.T.Kakhramanov, allowed to obtain a reliable picture of the nature of the melt flow of various types of composite materials $[3,9]$. Studies conducted in this direction hermit to predict the behavior of a polymer material in a viscous-fluid state. In a number of works, we have shown that nanoparticles in the composition of the polymer matrix radically change the nucleation mechanism. This circumstance is explained by the fact that in the melt of nanocomposites along with homogeneous, heterogeneous nucleation centers are formed. There is reason to believe that the microstructure of the polymer matrix in the presence of nanosized particles is fundamentally different from the structure formed by ordinary fine-dispersed fillers. This is due to the fact that nanoparticles interact with macrochains of the polymer matrix somewhat differently than larger particles, since the distance at which this contact occurs is commensurate with the size of the nanoparticles [10].

Figure $1(a, b)$ shows the flow curves of the melt of the initial $\mathrm{CEH}$ and $\mathrm{CEH}+5$ mass $\%$ CTL nanocomposite. The choice of this particular composite was due to the fact that we had previously established the sheer fact of maximum strength indicators at this filler concentration [11]. As can be seen from this Figure, the flow curves have a straight-line relationship, indicating that in the range of temperatures and shear stresses there are no fields of the largest and smallest Newtonian region. According to the Frenkel-Eyring theory, in this straight-line section, the rate of formation of macrosegment associates is equal to the rate of their destruction [8]. From Figure $1 b$, it can be established that in the temperature and shear stress range under consideration, the shear rate of the CEH + 5mass.\% CTL nanocomposite is 
comparatively higher than that of the initial CEH by $1.7-2.4$ times. Such a significant increase in the shear rate at the same fixed values of shear stress and temperature indicates that natural minerals contain nanoclay with a layered structure. As we noted earlier [8-10], the interlayer space of nanoclay contains polar liquids, glycerin, and surfactants. In the process of thermo-mechanical action on the composite melt, macrosegments of polymer macromolecules intercalate into the interlayer space of nanoclay with its subsequent decay, i.e. "exfoliation" of layer structures into smaller formations. In the process of exfoliation of nanoparticles, polar liquids present in the interlayer space migrate to the melt and like lubricating agents, improve the fluidity of the composite [9].

Based on the foregoing, it can be concluded that clinoptilolite exhibits bifunctionality, as it not only improves the strength characteristics [11], but also improves the rheological performance of nanocomposites.

This is confirmed by the results of a study of the effect of CTL concentration and temperature on the shear rate and effective viscosity of nanocomposites, as set forth in Table. Analyzing the data presented in this Table, it can be noted that with an increase in the filler concentration, a general tendency toward an increase in the shear rate is observed. At the concentration of CTL over 20 mass \% shear rate begins to decrease, remaining above the fluidity of the initial CEH. All these points are extremely important in relation to the technology of their processing by injection molding and extrusion. This is due to the fact that maintaining the fluidity of the melt of highly filled composites at a relatively high level provides the possibility of their processing by injection molding and extrusion.
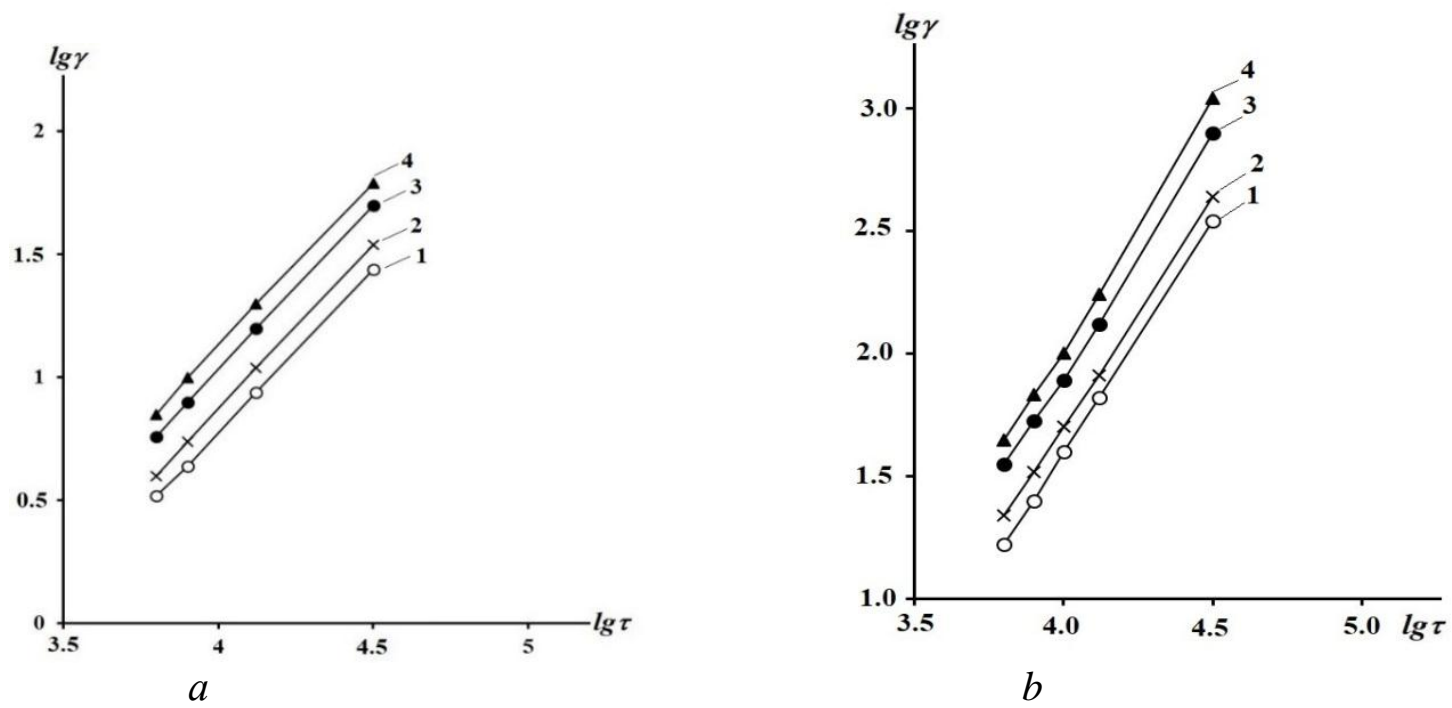

Fig. 1. Flow curves of the initial CEH $(a)$ and CEH+5 mass.\% CTL $(b)$ at various temperatures: $\circ-190, x-210, \bullet-$ 230 and $\boldsymbol{\Delta}-250^{\circ} \mathrm{C}$.

Effect of CTL concentration and temperature on shear rate and effective melt viscosity of CEH-based nanocomposites

\begin{tabular}{|l|c|c|c|c|c|c|c|c|}
\hline \multirow{2}{*}{$\begin{array}{c}\text { Composition formulation, } \\
\text { mass.\% }\end{array}$} & \multicolumn{4}{|c|}{ Shear rate, $\lg \gamma$} & \multicolumn{3}{c|}{ Effective melt viscosity, lgn } \\
\cline { 2 - 10 } & $190^{\circ} \mathrm{C}$ & $210^{\circ} \mathrm{C}$ & $230^{\circ} \mathrm{C}$ & $250^{\circ} \mathrm{C}$ & $190^{\circ} \mathrm{C}$ & $210^{\circ} \mathrm{C}$ & $230^{\circ} \mathrm{C}$ & $250^{\circ} \mathrm{C}$ \\
\hline CEH & 1.45 & 1.57 & 1.70 & 1.78 & 3.05 & 2.93 & 2.80 & 2.72 \\
\hline CEH+5.0 mass.\% CTL & 2.54 & 2.65 & 2.90 & 3.05 & 1.96 & 1.85 & 1.60 & 1.45 \\
\hline CEH+10 mass.\% CTL & 2.98 & 3.14 & 3.29 & 3.45 & 1.52 & 1.36 & 1.21 & 1.05 \\
\hline CEH+15 mass.\% CTL & 3.15 & 3.28 & 3.54 & 3.76 & 1.35 & 1.22 & 0.96 & 0.74 \\
\hline CEH+20 mass.\% CTL & 3.21 & 3.35 & 3.65 & 3.82 & 1.29 & 1.15 & 0.85 & 0.68 \\
\hline CEH+30 mass.\% CTL & 2.86 & 3.02 & 3.20 & 3.42 & 1.64 & 1.48 & 1.30 & 1.08 \\
\hline
\end{tabular}


For a comprehensive interpretation of the revealed patterns in the change in the melt flow of nanocomposites, Figure $2(a, b)$ shows the dependence of viscosity on shear rate in logarithmic coordinates. Analyzing the curves in Figure $2 a$, it can be noted that in the initial CEH, a sharp decrease in the melt viscosity is observed mainly at a temperature of $250^{\circ} \mathrm{C}$ and at relatively high shear rates. In contrast to the $\mathrm{CEH}$ in the $\mathrm{CEH}+5 \%$ mass. CTL nanocomposite, this dependence is mainly straight-line nature. This is confirmed by derivatographic analysis data. Such a sharp abrupt increase in the fluidity of the melt can be interpreted by partial leakage of thermal decomposition at $250^{\circ} \mathrm{C}$. According to derivatographic studies of the initial $\mathrm{CEH}$, thermal oxidative degradation proceeded at 242 $272^{\circ} \mathrm{C}$, then for nanocomposites based on the $\mathrm{CEH}+5$ wt.\% CTL, this process was recorded at a higher temperature: $265-285^{\circ} \mathrm{C}$.

According to the Frenkel-Eyring theory, at a fixed temperature, the rate of destruction and restoration of macrosegment associates becomes constant. However, if with an increase in shear stress the rates of these mutually opposite processes change at a given temperature, then a fracture is observed in the curve of the dependence of the effective viscosity on the shear rate. By macrosegment associations are meant primary acts of formation of homogeneous nucleation

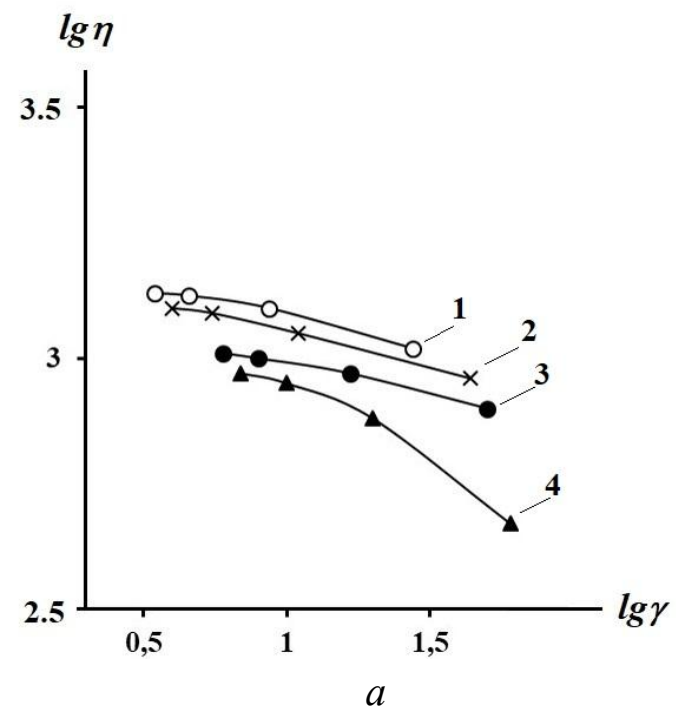

Fig. 2. The dependence of the effective viscosity $(\lg \eta)$ of the initial $\mathrm{CEH}(a)$ and the nanocomposite $\mathrm{CEH}+5 \mathrm{wt}$. \% CTL (b) on the shear rate $(\lg \gamma)$ in logarithmic coordinates at different temperatures, ${ }^{0} \mathrm{C}: \circ-190, \mathrm{x}-210, \bullet-230$ and $\boldsymbol{\Delta}-$ $250^{\circ} \mathrm{C}$. centers. The introduction of nanoparticles into the CEH promotes the formation of additionally heterogeneous nucleation centers. These centers are more stable, since they are formed on the developed surface of nanoparticles as a result of orientation processes. Orientation is enhanced by the adhesive interaction of macrochains on the surface of nanoparticles with the formation of a monolayer that can withstand relatively high temperatures and shear stresses in the melt. This circumstance, in fact, explains the relatively linear nature of the change in the dependence of the effective viscosity on temperature even at $250^{\circ} \mathrm{C}$.

Figure $3(a, b)$ shows the patterns of change in the effective viscosity of the melt as a function of temperature at various shear stresses. The study of this dependence in Arrhenius coordinates allows us to calculate the activation energy of the viscous flow of the studied objects. As can be seen from this figure, regardless of the type of sample used, the dependence of viscosity on temperature in semilogarithmic coordinates is nonlinear. In this connection, it becomes necessary to determine the "point" or "apparent" activation energy of the viscous flow of polymer materials. As a result of the studies, it was found that for the initial CEH the activation energy of the viscous flow varies in the range of 42-76 $\mathrm{kJ} / \mathrm{mol}$, while for a nanocomposite its value varies in the range of $38-65 \mathrm{~kJ} / \mathrm{mol}$.

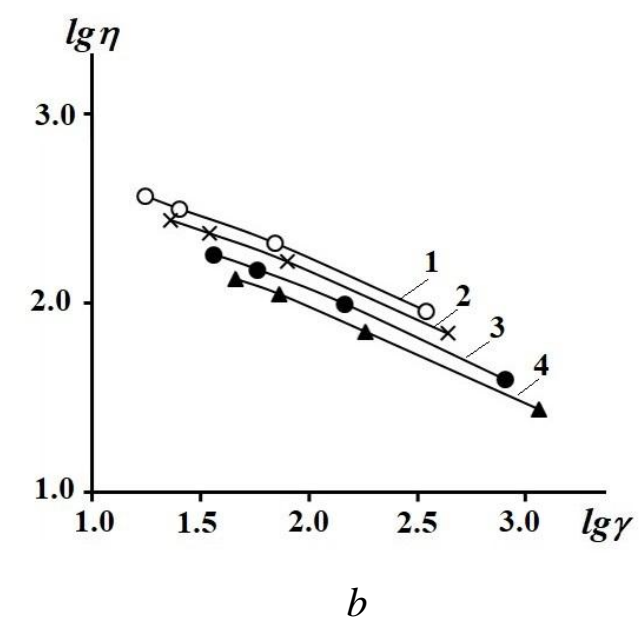



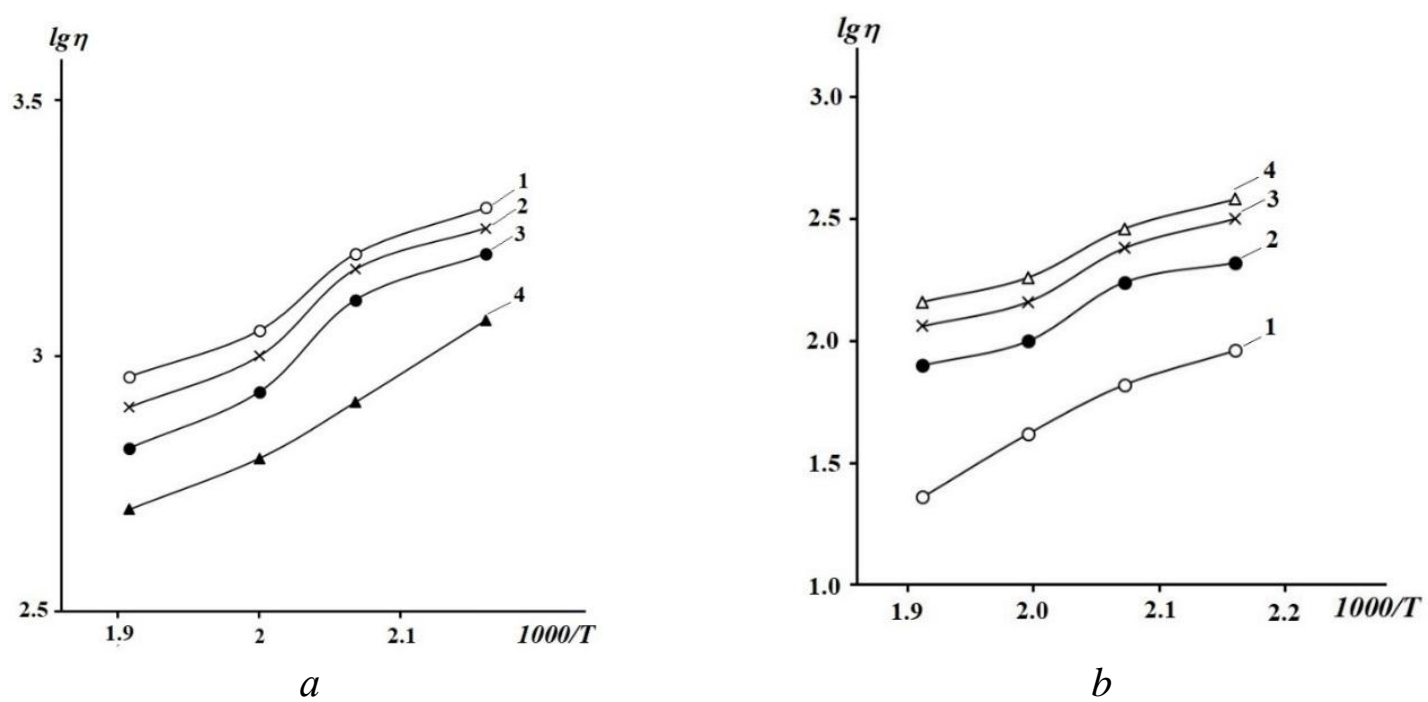

Fig. 3. Effective viscosity versus reciprocal temperature in the Arrhenius coordinates for the initial CEH (a) and nanocomposite $\mathrm{CEH}+5$ wt. $\%$ CTL $(b)$ at various temperatures, ${ }^{0} \mathrm{C}: \circ-190, \mathrm{x}-210, \bullet-230, \boldsymbol{\Delta}-250$.

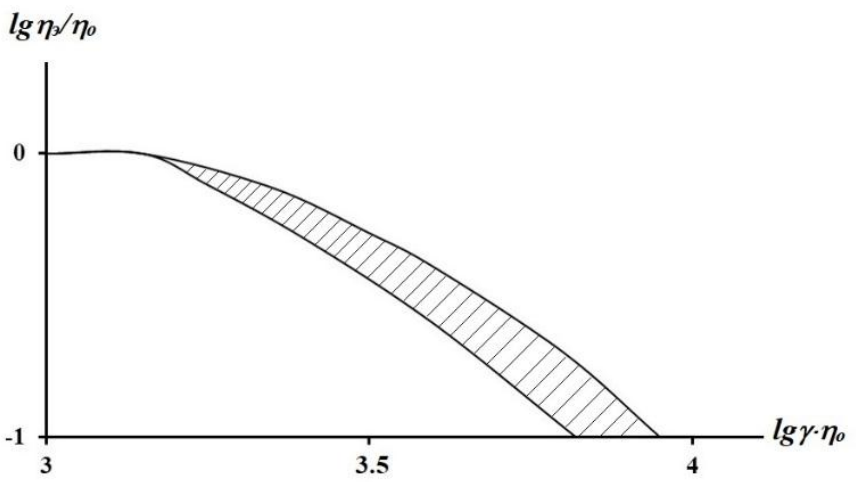

Fig. 4. Temperature-invariant characteristic of the dependence of the given viscosity $\left(\lg \eta_{\mathrm{e}} / \eta_{\mathrm{o}}\right)$ on the given shear rate $\left(\lg \gamma \cdot \eta_{\mathrm{o}}\right)$ of the initial CEH and nanocomposites based on CEH + CTL.

In practice, in the process of polymers processing, it becomes necessary to determine the effective viscosity of the melt at sufficiently higher shear rates. Especially when it comes to processing by methods such as injection molding and extrusion [12]. For this purpose, the most promising is the study of the temperatureinvariant characteristics of composite materials shown in Figure 4. Analyzing the data presented in this figure, at very low shear rates, the region of the highest Newtonian viscosity appears. By extrapolating these curves to the region of high shear rates, it is possible to determine the approximate value of the melt viscosity. As can be seen from this figure, with an increase in the given shear rate $\left(\lg \gamma \eta_{\mathrm{o}}\right)$, a regular decrease in the given viscosity $\left(\lg \eta_{9} / \eta_{0}\right)$ is observed. When the effective viscosity $\left(\eta_{\mathrm{e}}\right)$ is equated to the highest Newtonian viscosity $\left(\eta_{\mathrm{o}}\right)$, then the expression $\lg \eta_{\mathrm{e}} / \eta_{\mathrm{o}}$ becomes equal to zero. The existence of a universally invariant viscosity characteristic of the initial $\mathrm{CEH}$ and nanocomposites basis on the $\mathrm{CEH}+\mathrm{CTL}$ indicates the cooperative nature of the movement of associates in the melt flow.

\section{Conclusions}

Based on the foregoing, it can be stated that the introduction of the natural mineral CTL into the $\mathrm{CEH}$ composition can significantly improve the fluidity of the melt of nanocomposites. We studied such rheological characteris- 
tics as the dependence of shear rate on shear stress over a wide temperature range, the dependence of effective viscosity on shear rate and filler concentration, and the dependence of viscosity on temperature in Arrhenius coordinates. The apparent activation energy of the viscous flow of the initial $\mathrm{CEH}(42-76 \mathrm{~kJ} / \mathrm{mol})$ and nanocomposites, the values of which vary in the range $38-65 \mathrm{~kJ} / \mathrm{mol}$, was determined. As a result of a comprehensive study of the rheological properties of CEH-based nanocomposites, it was established that CTL has a dual function not only as a filler, but also as a lubricant that can improve their processability. The construction of a universal temperature-invariant characteristic of the viscosity properties of $\mathrm{CEH}$ and nanocomposites allows extrapolation of the reduced shear rate to the region of high shear rates close to their processing by extrusion and injection molding.

\section{References}

1. Berlin A.A., Volfson S.A., Oshman V.G. Principy sozdanija kompozicionnyh materialov. M.: Himija, 1990. $240 \mathrm{~s}$.

2. Simonov-Emeljanov I.D., Kuleznev V.N., Trofimicheva L.Z. Obobshhennye parametry dispersnoj sruktury napolnennyh polimerov. Plast. massy. 1989. No 1. S. 19-22.

3. Kakhramanov N.T., Ismailzade A.D., Arzumanova N.B., Mammadli U.M., Martinova Q.S. Filled composites based on polyolefins and clinoptilolite. Am. Sci. J. 2016. V. 4. No 4. P. 60-65.

4. Bessonova N.P., Krashennikov S.V., Korobko A.P. i dr. Struktura i svojstva nizkokristallicheskih poliolefinov, modificirovannyh nanoalmazami. Vysokomol. soed. 2015. T. 57. No 6. S. 544-554.

5. Osama Al Helo, Osipchik V.S., Petuhova A.V., Kravchenko T.P., Kovalenko V.A. Modifikacija napolnennogo polipropilena. Plast. massy. 2009. № 1. S. 43-46.

6. Osipchik V.S., Nesterenkova A.I. Talkonapolnennye kompozicii na osnove polipropilena. Plast. massy. 2007. № 6. S. 44-46.

7. Ermakov S.N., Kerber M.L., Kravchenko T.P. Himicheskaja modifikacija i smeshenie polimerov pri reakcionnoj jekstruzii. Plast. massy. 2007. № 10. S. 32-41.

8. Peseckij S.S., Bogdanovich S.P. Nanokompozity poluchaemye dispergirovaniem glin $\mathrm{V}$ rasplavah polimerov. Tez.dokl. Mezhdun. Nauchno-tehnich. Konfer. «Polimernye kompozity i tribologija». Gomel, 2015. S. 5.

9. Kakhramanov N.T., Mustafayeva F.A., Arzumanova N.B., Hamedova L.H., Ljaljaeva R.N. Reologicheskie svojstva polimernyh smesej na osnove polijetilena nizkoj i vysokoj plotnosti. Kompozity i nanostruktury. 2018. T. 10. № 4(40). S. 166-170.

10. Cherdynceva S.V., Belousov S.I., Krasheninnikov S.V. i dr. Vlijanie vida organicheskogo modifikatora montmorillonita na fiziko-himicheskie svoystva nanokompoztitov na osnove poliamida-6, poluchennyh smesheniem $\mathrm{v}$ rasplave. Plast. massy. 2013. № 5. S. 39-43.

11. Kahramanov N.T., Bayramova I.V., Mamedli U.M. Deformacionno-prochnostnye svojstva napolnennyh polimernyh materialov. Elmi mecmueler, Milli Aviasiya Akademiyasi. 2017. No 3. S. 47-54.

12. Kakhramanov N.T., Huseynova Z.N., Osipchik V.S., Kurbanova R.V., Arzumanova N.B. Reaction extrusion of dynamic elastoplasts on the basis of polyolefines and butadien-nitril rubber. Azerb. chem. journ. 2019. № 1. S. 65-71.

\section{BİFUNKSIONAL KLİNOPTILOLIT VӘ ETILLENIN HEKSEN İLə BİRGəPOLİMERİ OSASINDA NANOKOMPOZITLORIN REOLOJI XASSЭLӘRİ}

\section{I.V.Bayramova}

Temperaturun və yerdəyişmə gərginliyinin etilenin heksen ilə birgəpolimerinin və onun klinoptilolit ilə doldurulmuş nanokompozitlərinin reoloji xassələrinə təsirinin tədqiqinin nəticələri təqdim olunur. Reoloji ölçmələr $190-250^{\circ} \mathrm{C}$ temperatur diapazonunda həyata keçirilmişdir. Yerdlyişmə sürətinin yerdəyişmə gərginliyindən, ərintinini effektiv özlülüyünün yerdəyişmə sürətindən, arrenius koordinantlarında ərintinin özlülüyünün temperaturdan asılllı̆̆ öyrənilmişdir. Nanokompozitlərin özlülük xassələrinin universal temperatur-invariant xüsusiyyətlərinin istifadəsi yüksək yerdəyişmə sürətləri sahəsinə ekstrapolyasiya yolu ilə onların ekstruziya və təzyiq altında tökmə üsulları ilə emal şəraitiniə yaxın effektiv özlülüyünün təqribi hesablamalarını həyata keçirməyə imkan verir.

Açar sözlor: özlülük, yerdayişmə sürəti, yerdəyişma garginliyi, nanokompozitlar, polimer arintisi, klinoptilolit 


\section{РЕОЛОГИЧЕСКИЕ СВОЙСТВА НАНОКОМПОЗИТОВ НА ОСНОВЕ БИФУНКЦИОНАЛЬНОГО КЛИНОПТИЛОЛИТА И СОПОЛИМЕРА ЭТИЛЕНА С ГЕКСЕНОМ}

\section{И.В.Байрамова}

Приводятся результаты исследования влияния температуры и напряжения сдвига на реологические свойства сополимера этилена с гексеном и его наполненных клиноптилолитом нанокомпозитов. Реологические измерения проводились в температурном диапазоне $190-250^{\circ} \mathrm{C}$. Изучена зависимость скорости сдвига от напряжения сдвига, эффективной вязкости расплава от скорости сдвига, зависимости вязкости расплава от температуры в аррениусовских координатах. Использование универсальной температурно-инвариантной характеристики вязкостных свойств нанокомпозитов позволило путем экстраполяции в область высоких скоростей сдвига производить приближенные расчеты эффективной вязкости, близкой к условиям их переработки методами экструзии и литья под давлением.

Ключевые слова: вязкость, скорость сдвига, напряжение сдвига, нанокомпозиты, расплав полимера, клиноптилолит. 